Mark N. Katz

\title{
PROSPECTS FOR THE U.S.-RUSSIA COOPERATION IN THE MIDDLE EAST IN THE TRUMP ERA
}

DOI: $10.20542 / 2307-1494-2017-1-171-181$

Keywords: U.S.-Russia relations, Middle East, Syria, Iraq, ISIL, Turkey, the Kurds, Israel, Egypt, Libya, Yemen, Gulf Cooperation Council, Iran

Abstract: The article discusses the rise and fall of expectations of improvement of the U.S.Russia relations at the outset of the Trump administration and then analyzes how Washington's and Moscow's interests in the Middle East converge or diverge. The author argues that, despite the unlikelihood of any major U.S.-Russia rapprochement, Washington's and Moscow's interests in the Middle East either overlap or, at least, do not oppose each other (except regarding Iran). Moscow's and Trump's administration's pragmatic, transactional view of foreign policy suggests it is possible for them to work together on the Middle East even though bilateral relations remain at odds in other areas. This, however, may not be sufficient to result in meaningful U.S.-Russian direct cooperation in the Middle East since there are other obstacles to it, including domestic constraints in the United States on cooperation with Russia and the readiness of some Middle Eastern governments to exploit the U.S.-Russia rivalry in their own interests. Even so, the U.S. and Russia's support for many of the same governments in the Middle East and to fight against ISIL may serve to foster cooperation and limit confrontation between them in this region. Successful cooperation between the United States and Russia in the Middle East, in turn, could enhance the prospects for their cooperation elsewhere.

Ключевые российско-американские отношения, Ближний Восток, Сирия, Ирак, ИГИЛ, слова: Турция, курды, Израиль, Египет, Ливия, Йемен, Совет сотрудничества стран Персидского залива, Иран

Аннотация: В статье обсуждаются подъем и спад ожиданий улучшения российскоамериканских отношений с приходом к власти администрации Трампа, а затем анализируется общее и различное в интересах Вашингтона и Москвы на Ближнем Востоке. Автор приходит к выводу о том, что, несмотря на низкую вероятность полноценного сближения США и России, интересы Вашингтона и Москвы на Ближнем Востоке либо пересекаются, либо, по крайней мере, не противоречат друг другу (за исключением политики в отношении Ирана). Прагматичные подходы как Москвы, так и администрации Трампа к внешней политике делают для них возможным сотрудничество по Ближнему Востоку, даже если отношения между ними в других областях пробуксовывают. Этого, однако, может быть недостаточно для налаживания сколько-нибудь существенного прямого российскоамериканского взаимодействия на Ближнем Востоке, так как для него существуют и иные препятствия, включая внутриполитические ограничения в США на сотрудничество с Россией, а также готовность ряда ближневосточных государств использовать соперничество между США и Россией в своих интересах. Тем не менее одновременная поддержка многих 
государств в регионе и США, и Россией, а также предпринимаемые обеими странами усилия по борьбе с ИГИЛ могут способствовать сотрудничеству и ограничить конфронтацию между ними на Ближнем Востоке. В свою очередь, любое успешное взаимодействие между США и Россией на Ближнем Востоке может улучшить перспективы их сотрудничества и по другим проблемам и регионам.

\section{Introduction}

During the 2016 U.S. presidential election campaign, Russia's President Vladimir Putin expressed positive views about Donald Trump (also according to Trump himself), and Trump expressed positive views about Putin. Both indicated that it was not just desirable, but possible to improve the state of the U.S.-Russian relations, and that the two countries had common interests in many areas that they could and should cooperate on. Putin and Trump both singled out the possibility of Moscow and Washington working together against the Islamic State in Syria and the Levant (ISILalso known as ISIS and Islamic State) as something that would benefit both countries as well as the region and the international security as a whole.

However, despite hopes for an overall improvement in the U.S.-Russian relations, Moscow and Washington still disagree on several issues - including Crimea, eastern Ukraine, sanctions, and NATO - just as they did before. There is also the added controversy about the Trump campaign's relationship with Russia that has affected the bilateral relationship.

These factors obviously complicate the prospects for the Russian-American cooperation in the Middle East, but they do not necessarily preclude it. The rise and fall of expectations about Russian-American relations at the outset of the Trump administration will be discussed here first, followed by an analysis of how Washington's and Moscow's interests in the Middle East converge or diverge.

\section{U.S.-Russian relations: clouds not parting}

When Trump was elected president in November 2016, the prospects for the U.S.Russian cooperation initially seemed quite good. Some of the people close to Trump during his presidential campaign were also strong advocates of improved RussianAmerican relations. ${ }^{1}$

However, things did not remain smooth for long. Even before taking office, president-elect Trump indicated that he would seek to increase the American nuclear arsenal. ${ }^{2}$ Also, some of Trump's other appointees - including Jim Mattis as Secretary of Defense and Nikki Haley as the U.S. Ambassador to the UN - had much more negative views about Russia. Even Trump's choice for the Secretary of State - former chief executive of "Exxon Mobil" Rex Tillerson - who some thought would be pro-Russian turned out not to be. Further, Russia-friendly General Michael Flynn was soon dismissed, due to not fully disclosing his contacts with Moscow's ambassador in 
Washington, and was replaced by Russia-skeptic General Herbert Raymond McMaster as National Security Adviser. ${ }^{3}$

It also became clear that Trump was not going to alter the policies of the Barack Obama administration in areas of particular concern to Russia, including sanctions, Crimea, eastern Ukraine, and NATO ${ }^{4}$ Growing public concern in the U.S. about ties between Trump and some of his close associates on the one hand and Russia on the other suggest that Trump's efforts to improve relations with Moscow could have negative domestic political ramifications for him. ${ }^{5}$ Finally, when Putin proposed extending the New Strategic Arms Reduction Treaty (START) during his phone call with Trump on 28 January 2017, Trump responded that this had been a "bad deal" for America and made clear that he really did want to increase the U.S. nuclear arsenal ${ }^{6}-$ which was not what Putin wanted to hear. Indeed, the relatively positive tone toward Trump that the Russian media had adopted after his election and inauguration disappeared in midFebruary and was replaced by a more reserved or more negative one. ${ }^{7}$ Russian expectations that the Trump administration would change U.S. foreign policy in ways favorable to Moscow have diminished greatly.

From the time that Trump emerged as a serious presidential contender in early 2016 until just after his inauguration in January 2017, the U.S.-Russian cooperation in the Middle East that Trump and Putin had called for was part of a broader RussianAmerican reconciliation that both leaders appeared to envision. It is now clear, however, that that broader reconciliation is not going to occur, due both to differences between the United States and Russia over other key issues (including Ukraine, European security, and nuclear weapons) and political concerns shared by Republicans as well as Democrats over Trump's ties to Russia which limit his ability to cooperate with it. The question that arises, then, is can Washington and Moscow cooperate, or at least avoid clashing, with each other in the Middle East in an atmosphere where serious differences between them remain elsewhere?

\section{Silver lining in the Middle East?}

The possibility of reviving and stepping up the U.S.-Russia cooperation in the Middle East must be considered a serious one, since Moscow and the Trump administration appear to have much more convergent views on the Middle East than Russia and the United States did during the Obama administration (even as there had been some overlap then, too). What is most important for Moscow is that the Trump administration does not intend to attempt to democratize the Middle East, but is comfortable working with most existing governments (authoritarian or otherwise) there instead. Trump, then, is closer to Putin on this issue than to either Obama, or George W. Bush (who, it should not be forgotten, articulated an ambitious plan to democratize the greater Middle East back in 2003). ${ }^{8}$ Still, the commitment of administrations of G.W.Bush and B.Obama to democratize the Middle East should not be exaggerated either: in practice, they pursued this goal when they thought it was 
achievable, but distanced themselves from it when it proved not to be. Still, Bush's and Obama's pursuit of it as a foreign policy goal aroused Moscow's suspicions about their ultimate aims in doing so that the Trump administration's policy does not. ${ }^{9}$ This alone could serve to increase the prospects for the U.S.-Russian cooperation in the Middle East.

In Syria (and Iraq), the Trump administration - much like the Obama administration before it - opposes ISIL. There is also much continuity in the Trump administration's support to the Syrian Kurds who are fighting against ISIL on the ground. In the past, Russia and the United States differed sharply on whether Bashar al-Assad should remain president of Syria (with Moscow seeing the Assad regime as an ally against terrorism while Washington under the Obama administration saw him as the cause of it). ${ }^{10}$ Now, while Trump does not support the Syrian regime, even the Russian media describes him as not insisting on Assad's removal like Obama did. ${ }^{11}$ This increases the chances for Washington and Moscow to cooperate or at least coordinate more actively on defeating ISIL. There is, however, conflict among rival groups in Syria seeking to displace ISIL in the remaining territory it controls. ${ }^{12}$ On the one hand, the Trump administration's plan to increase the U.S. military presence in Syria aimed at combating ISIL clashes with Moscow's insistence that outside governments need to obtain the Assad regime's approval for deploying armed forces in Syria. On the other hand, Russia's hopes for obtaining economic support from the West and the Arab Gulf states for reconstruction efforts in Syria gives Moscow a major incentive to cooperate with Washington and its allies in Syria. ${ }^{13}$ Thus, while the potential for the U.S.-Russian policy disagreements on Syria is still significant, there is also potential for Putin and Trump to cooperate on conflict management there.

Relations with Turkey have been problematic for Russia, as well as for the United States and other Western countries, although for different reasons. The Russian-Turkish relations soured when Turkish armed forces shot down a Russian warplane flying near the Turkish-Syrian border in November 2015, but improved when President Recep Tayyip Erdogan apologized to Putin for the incident in June 2016 and especially when Erdogan saw Moscow as more supportive than the West during the failed coup attempt against him in July 2016. ${ }^{14}$ After the uprising against the Assad regime that began in 2011, Ankara and the Obama administration shared the goal of wanting to see Assad and his close circle leave office. However, Turkey and the United States each sometimes objected to the Syrian groups which the other supported. ${ }^{15}$ The United States (both under Obama and under Trump) and Russia have been supporting Kurdish Syrian forces whom they see as highly effective in fighting against ISIL. ${ }^{16}$ In contrast, Turkey sees the Syrian Kurds as linked to the "terrorist" PKK, the Kurdish movement seeking secession from Turkey. While the U.S. support for the Syrian Kurds would seem to present an opportunity for Moscow to side with Erdogan on an issue of great importance to him, Moscow also has good relations with the Syrian Kurds and has indicated support for their calls for a federal solution to the Syrian conflict. ${ }^{17}$ Instead of disagreeing on Turkey, Putin and Trump both face a similar challenge of trying to 
maintain good relations with Erdogan while at the same time cooperating with the Syrian Kurds - perhaps, the only force in Syria whom Washington and Moscow both support.

On Israel, Trump is far more supportive of the hardline government of Benjamin Netanyahu and is much less sympathetic to the plight of the Palestinians than the Obama administration was. ${ }^{18}$ Russia, of course, has long expressed support for the Palestinian cause. Under Putin, though, relations between Russia and Israel have steadily developed and have grown quite strong. Russia and Israel cooperate closely in the security, economic, and cultural realms. Further, while Russia always declares its support for the Palestinian cause and criticizes Israel's continued occupation of the West Bank and the blockade of the Gaza Strip, Moscow's differences with Tel-Aviv on this issue have not prevented them from cooperating closely in the economic and even the security realms. ${ }^{19}$ Despite Moscow's rhetorical support for the Palestinian cause, Russia has not given serious material support for Palestinian opposition to Israel. Thus, while their rhetoric toward the Israeli-Palestinian dispute may differ, Moscow and Washington under the Trump administration both cooperate closely with the Netanyahu government. For his part, Netanyahu appears far more comfortable with both Putin and Trump than he was with Obama. ${ }^{20}$ Israel as such, then, is unlikely to be a point of contention between Putin and Trump.

On Egypt, both the Kremlin and the White House have - unlike Obama - been highly supportive of the "post-Arab Spring" government of Abdul Fattah al-Sisi. In contrast, the Obama administration imposed (admittedly weak) limits on the U.S. arms exports to Egypt after General al-Sisi overthrew the elected government of Muslim Brotherhood leader Mohammed Morsi in 2013. Like Moscow (as well as several Arab governments), the Trump administration has a negative view the Muslim Brotherhood and sees the military government in Cairo as preferable alternative to it. ${ }^{21}$ On Egypt, then, Russia and the United States are increasingly on the same side.

On Libya, Moscow was angry that the Obama administration and other U.S. allies intervened in 2011 to overthrow the ruling regime of Russia's longtime friend, Muammar Qaddafi. President Putin and Russia's official diplomacy blamed Obama in particular for the chaos that ensued in Libya after Qaddafi's downfall. ${ }^{22}$ While joining the United States, the EU and others in recognizing the UN-sponsored Libyan government of national accord based in Tripoli (in the west of the country), Russia has been supporting one of its challengers, General Khalifa Haftar, in the east. Reuters recently reported that 22 Russian special operations forces have been deployed to a base in western Egypt about 60 miles from the Libyan border. It is believed that they are assisting General Haftar from there. ${ }^{23}$ Russia, however, is not supporting him on its own, but in conjunction with the U.S. allies Egypt, the UAE, and even France. ${ }^{24}$ So even as Moscow is not cooperating with Washington directly in Libya, it is cooperating or acting in line with some of the U.S. allies there.

Russia has not sought to become militarily involved in the region's other ongoing conflicts in Iraq and Yemen where the U.S. has been more engaged. Moscow strongly opposed and was especially upset with the G.W.Bush administration for having 
intervened in Iraq in 2003 without the UN Security Council (i. e. Russian) approval. Still, Moscow was able to establish good working relations with the Baghdad governments during the Bush and Obama years and was broadly supportive of the Obama administration's efforts to help both Iraqi government and the Kurdish forces contain and then roll back ISIL's advance. ${ }^{25}$

The Saudi and UAE intervention in Yemen in support of the deposed president, Abdrabbuh Mansour Hadi, was backed by the United States, first by the Obama administration and then by Trump (although the U.S. Special Operations Forces raid in Yakia (central Yemen), authorized by Trump shortly after he took office and carried out on January 29, 2017, to gather intelligence on "al-Qaeda in the Arabian Peninsular" did not go well). ${ }^{26}$ As in Iraq, Russia has not been deeply involved in Yemen. While Moscow (along with the UN and the international community) recognizes the Hadi government, it is also talking with the Houthi movement that represents Yemen's Zaidi Shia minority and is a lead rebel force opposing Hadi and the Saudis. The United States has been supporting the Saudi intervention to back Hadi against the Houthi insurgency. ${ }^{27}$

While Moscow and Washington do not appear to be cooperating in Iraq and Yemen, they are at least not working directly against each other there either.

Under the Obama administration, the U.S. relations with several of the Gulf Cooperation Council (GCC) states became strained because of Washington's pursuit of the Iranian nuclear accord (reached in 2015) and hopes for a broader rapprochement with Tehran, which the Arab Gulf states have long seen as the main regional threat to them. In response to their perception that Obama was moving closer to Iran, some of the GCC states explored contacts with Russia, even despite Moscow's strong, stable and long-term relations with Tehran. ${ }^{28}$ The Trump administration's negative view of Iran is much more reassuring to the GCC states. Still, they continue to maintain and improve relations with Russia, even despite disagreements on the conflict in Syria (for instance, Qatar has acquired a major stake in the Russian petroleum giant "Rosneft" while the UAE is working with Russia on developing a new fighter aircraft). ${ }^{29}$ Furthermore, Russia does not seem to be trying to displace the U.S. as the main security partner for the GCC. Although Russia's cooperation with the GCC states is not nearly as extensive as the United States', both Washington and Moscow broadly support GCC governments.

Iran is the one Middle Eastern country where the U.S. and Russia's policies diverge sharply. While Trump and his principal advisers have an extremely negative view of Iran, Moscow clearly sees Tehran as a partner, especially in Syria. Interestingly, the Trump administration initially hoped that the prospect of an improved U.S.-Russian relationship could motivate Russia to move away from Iran. ${ }^{30}$ Moscow, though, has shown no sign of being interested in doing this. ${ }^{31}$ Russia's and the U.S. views of Iran, then, appear likely to remain divided. Trump's differences with Iran could also result in differences with Russia. Still, even though Washington and Moscow largely differ on Iran, there may be some overlap: while Trump declared that he would "tear up" the 2015 Iranian nuclear deal when he was running for office, he has not yet done so since becoming president. ${ }^{32}$ Even the anti-Iranian governments in the GCC and Israel that 
initially opposed the Iranian nuclear accord now reportedly prefer to leave the deal in place. ${ }^{33}$ Russia also wants to see it remain in effect.

\section{Conclusion}

Despite the unlikelihood of any major overall U.S.-Russia rapprochement in the foreseeable future or a resolution of their differences on sanctions, Ukraine, and NATO, Washington's and Moscow's interests in the Middle East either overlap or, at least, do not oppose each other (except regarding Iran). Since both Putin's and Trump's administrations take a transactional view of foreign policy, this suggests that they both are capable of cooperating in areas where their interests converge even when there are other areas where they diverge. This ability, however, may not be sufficient to result in meaningful U.S.-Russian direct cooperation in the Middle East since there are other factors that would tend to limit this.

The Trump administration will first have to overcome suspicions in the United States shared by Democrats and many Republicans about his being either too close to Putin or even being beholden to him. Unless Trump can do this, any effort by him to cooperate with Moscow will raise doubts and political and media speculations in the United States and among the U.S. allies about whether Trump is acting primarily in America's interest or Russia's.

But even if this obstacle can be overcome, there are others. While, as noted earlier, Moscow and Washington mostly support the same Middle Eastern governments (Syria and Iran being the exceptions), this may not be enough to bring about positive cooperation between them. Also, both strongly oppose ISIL in Syria (and Iraq). Washington and Moscow would each prefer, though, that ISIL be defeated and its territory taken over by its own respective allies and not the other's. The closer to achievement the common goal of defeating ISIL in Syria appears, the more this could lead to disharmony between the U.S. and Russia (among others) there.

Another problem is that while Moscow and Washington now have good relations with most Middle Eastern governments, these governments are well aware of the tension and rivalry between the United States and Russia regarding other areas and issues. Middle Eastern states' cooperation with Russia in particular may be undertaken to induce the Trump administration and other Western governments to respond by providing more than they are now to regional governments, so that they will not move even closer to Russia. Many in the Middle East actually welcomed the return of the U.S.Russia rivalry as an opportunity to play Moscow and Washington off against each other. ${ }^{34}$ The recent revival of Russia's active involvement in the Middle East, though, has made this possible again. The U.S.-Russia rivalry, then, is something that at least some Middle Eastern governments are going to try to exploit. Their success in doing so, of course, may serve to exacerbate it.

While, under the Trump administration, Washington and Moscow may only really oppose each other in the Middle East on Iran, this is an important difference between 
them. Considering how much Moscow and Tehran cooperate with regard to Syria as well as bilaterally in the security and economic realms, it does not seem likely that Russia will distance itself from Iran in order to please Washington. Similarly, Trump seems unlikely to think more positively about Iran simply because Moscow does. Even if Moscow were willing, it is doubtful that it would be able to mediate between Washington and Tehran. Indeed, if the Iranian-U.S. relations deteriorate sharply to the point of conflict, Moscow is likely to at least express support for Tehran, and perhaps even do more. This could easily lead to increased tension, if not a crisis, in the U.S.-Russia relations.

While it is possible, then, that Washington and Moscow can work together on the Middle East even though bilateral relations remain at odds in other areas, there are also important obstacles within the Middle East itself to the U.S.-Russia cooperation there. Indeed, these obstacles would still exist even if the initial hopes that both Putin and Trump appear to have had for the improvement of the overall Russian-American relationship had been realized. Even so, despite their differences outside of the region and over Iran inside it, the U.S. and Russia's support for many of the same governments in the Middle East may serve to foster cooperation and limit confrontation between them in this region. Successful cooperation between the United States and Russia in the Middle East, in turn, could serve to enhance the prospects for their cooperation elsewhere.

\section{ENDNOTES}

\footnotetext{
1 Helderman R.S., Hamburger T. Flynn episode "darkens the cloud" of Russia that hangs over Trump administration // Washington Post. 14 February 2017. URL: <https://www.washingtonpost.com /politics/flynn-episode-darkens-the-cloud-of-russia-that-hangs-over-trump-administration/2017/02/14/ bc8d752a-f2db-11e6-8d72-263470bf0401_story.html?utm_term=.b246b99c5da5>.

2 Morello C. Trump says he wants to "greatly strengthen and expand" U.S. nuclear capability // Washington Post. 22 December 2016. URL: <https://www.washingtonpost.com/world/nationalsecurity/donald-trump-says-he-wants-to-greatly-strengthen-and-expand-us-nuclear-capabilitiy-aradical-break-from-us-foreign-policy/2016/12/22/52745c22-c86e-11e6-85b5-76616a33048d_story. html?hpid=hp_hp-top-table-main_trumpnuke110pm\%3Ahomepage\%2Fstory\&tid=a_inl\&utm_term $=81 \mathrm{~b} 71465 \mathrm{~d} 8 \overline{7} \overline{\mathrm{s}}>$

3 Rubin J. Russia hawks won the personnel battle, but they need to do more // Washington Post. 22 February 2017. URL: <https://www.washingtonpost.com/blogs/right-turn/wp/2017/02/22/russiahawks-won-the-personnel-battle-but-they-need-to-do-more/?utm_term=.0408874bd5da>.

4 Rogin J. Tillerson to testify Russia must be held to account for its actions // Washington Post. 10 January 2017. URL: <https://www.washingtonpost.com/news/josh-rogin/wp/2017/01/10/tillersonto-testify-russia-must-be-held-to-account-for-its-actions/?utm_term=.98807d0d6002>.
} 
5 Rubin J. Voters don't like what they see from Trump on Russia // Washington Post. 8 March 2017. URL: <https://www.washingtonpost.com/blogs/right-turn/wp/2017/03/08/voters-dont-like-what-theysee-from-trump-on-russia/?utm_term=.91708d9f0d5b>.

6 Roth A. Trump's Russia strategy collides with foreign policy reality in leaked call with Putin // Washington Post. 10 February 2017. URL: <https://www.washingtonpost.com/world/trumps-russiadetente-collides-with-foreign-policy-reality-in-leaked-call-with-putin/2017/02/10/4dedd4fa-ef7c-11e6b4ff-ac2cf509efe5_story.html?utm_term=.e1c0db3bda73>.

7 Crowley M. Kremlin-backed media turns on Trump // Politico. 7 March 2017. URL: <http://www.politico.com/story/2017/03/donald-trump-russia-media-235755>.

${ }^{8}$ President Bush discusses freedom in Iraq and Middle East. - Washington D.C.: The White House, 6 November 2003. URL: <https://georgewbush-whitehouse.archives.gov/news/releases/2003/11/ 20031106-2.html>.

9 On how Putin views American support for democratization in other countries as threatening, see Hill F., Gaddy C.G. Mr. Putin: Operative in the Kremlin. New and expanded edition. - Washington, DC: Brookings Institution Press, 2015. P. 305-307.

10 Stent A.E. The Limits of Partnership: U.S.-Russian Relations in the Twenty-First Century. -Princeton: Princeton University Press, 2014. P. 249-250.

11 Muraviev A. Trump administration abandons US initial priority in Syria to oust Assad // Sputnik International. 6 March 2017. URL: <https://sputniknews.com/middleeast/201703061051307093-ussyria-strategy/>.

12 Sly L. With a show of stars and stripes, U.S. forces in Syria try to keep warring allies apart // Washington Post. 8 March 2017. URL: <https://www.washingtonpost.com/world/middle_east/with-ashow-of-stars-and-stripes-us-forces-in-syria-try-to-keep-warring-allies-apart/2017/03/08/c77671a80352-11e7-9d14-9724d48f5666_story.html?utm_term=.61753615cbe8>.

${ }^{13}$ Russian hopes in this regard were aired at the Valdai Discussion Club conference on the Middle East held in Moscow on 27-28 February 2017, which the author attended.

14 Putin mends broken relations with Turkey's Erdogan // BBC News. 9 August 2016.

URL: <http://www.bbc.com/news/world-europe-37018562>.

${ }^{15}$ Idiz S. Turkish-US ties face fresh turbulence over Iraq, Syria // Al-Monitor. 12 January 2016. URL: $<$ http://www.al-monitor.com/pulse/originals/2016/01/turkey-usa-relations-iraq-syrian-kurds-potentialflashpoints.html>.

16 Khlebnikov A. The Kurds could bring Russia and the US together in Syria // Russia Direct. 29 October 2015. URL: <http://www.russia-direct.org/analysis/kurds-could-bring-russia-and-ustogether-syria>; Yinanç B. US, Russia will never give up the Kurdish card in Syria // Hurriyet Daily News. 13 March 2017. URL: <http://www.hurriyetdailynews.com/us-russia-will-never-give-up-thekurdish-card-in-syria.aspx?page|D=238\&nID=110699\&NewsCatID=352>.

17 Bozarslan M. Syria rejects Russian proposal for Kurdish federation // Al-Monitor. 24 October 2016. URL: <http://www.al-monitor.com/pulse/originals/2016/10/turkey-russia-mediates-between-kurds-and -assad.html>. 
${ }^{18}$ Gearan A., Eglash R. U.S. official: Trump will not press "two-state" peace track in first talks with Israel's Netanyahu // Washington Post. 15 February 2017.

URL: <https://www.washingtonpost.com/world/national-security/expectations-are-high-on-both-sidesfor-trumps-first-meeting-with-israeli-prime-minister-netanyahu/2017/02/14/f18041ac-f2dd-11e6-8d72263470bf0401_story.html?utm_term=.8c4fa81a27cc>.

19 Borshchevskaya A. Russia in the Middle East: Motives, Consequences, Prospects. Washington D.C.: Washington Institute for Near East Policy, 2016. P. 43-44.

20 Eglash R. Israel and Russia: BFFs? Netanyahu's budding "bromance" with Putin // Washington Post. 8 June 2016. URL: <https://www.washingtonpost.com/news/worldviews/wp/2016/06/08/israeland-russia-bbfs-netanyahus-budding-bromance-with-putin/?utm_term=.857059641686>; Landler M. For Trump and Netanyahu, a budding symbiotic relationship // New York Times. 7 March 2017. URL: <https://www.nytimes.com/2017/03/07/world/middleeast/israel-benjamin-netanyahu-trump.html>.

${ }^{21}$ Borshchevskaya A. Op. cit. P. 20-23; Dergham R. Egypt bets on strategic relations with Trump and Putin // Al Arabiya English. 4 December 2016. URL: <https://english.alarabiya.net/en/views/ news/middle-east/2016/12/04/Egypt-bets-on-strategic-relations-with-Trump-and-Putin.html>.

22 Stent A.E. Op. cit. P. 247-249.

23 Stewart P., Ali I., Noueihed L. Exclusive: Russia appears to deploy forces in Egypt, eyes on Libya role - sources // Reuters. 14 March 2017. URL: <http://www.reuters.com/article/us-usa-russia-libyaexclusive-idUSKBN16K2RY>.

24 Bibbo B. Can Russia resolve the conflict in Libya? // Al Jazeera. 16 March 2017. $<\mathrm{http}: / / w w w . a l j a z e e r a . c o m / i n d e p t h / f e a t u r e s / 2017 / 03 /$ russia-resolve-conflict-libya170316094138550.html>.

${ }^{25}$ Borshchevskaya A. Op. cit. P. 31-35.

${ }^{26}$ Schmitt E. U.S. commando killed in Yemen in Trump's first counterterrorism operation // New York Times. 29 January 2017. URL: <https://www.nytimes.com/2017/01/29/world/middleeast/ americancommando-killed-in-yemen-in-trumps-first-counterterror-operation.html?_r=0>.

27 Katz M.N. Russia maneuvers between opposing forces in Yemen // Arab Gulf States Institute in Washington. 25 January 2017.

URL: <http://www.agsiw.org/russia-maneuvers-opposing-forces-yemen>.

${ }^{28}$ Borshchevskaya A. Op. cit. P. 41-44; Katz M.N. Convergent hopes, divergent realities: Russia and the Gulf in a time of troubles // Arab Gulf States Institute in Washington. 6 November 2015.

URL: <http://www.agsiw.org/convergent-hopes-divergent-realities-russia-and-the-gulf-in-a-time-oftroubles/ \#sthash.7nDJNiic.dpuf>.

29 Mazneva E., Arkhipov I. Russia sells $\$ 11$ billion stake in Rosneft to Glencore, Qatar // Bloomberg. 7 December 2016. URL: <https://www.bloomberg.com/news/articles/2016-12-07/glencore-qatar-fundbuy-russia-s-rosneft-stake-for-11-billion>; Rahman F. UAE, Russia to develop light combat fighter jet // Gulf News. 20 February 2017. URL: <http://gulfnews.com/business/economy/uae-russia-todevelop-light-combat-fighter-jet-1.1981695>. 
30 Solomon J. Trump administration looks at driving wedge between Russia and Iran // Wall Street Journal. 5 February 2017. URL: <https://www.wsj.com/articles/trump-administration-looks-at-drivingwedge-between-russia-and-iran-1486342035>.

${ }^{31}$ Katz M.N., Ibish H. Why Moscow won't side with Washington against Tehran // Arab Gulf States Institute in Washington. 7 March 2017. URL: <http://www.agsiw.org/moscow-wont-side-washingtontehran/>.

${ }^{32}$ Andelman D.A. Why Trump won't tear up Iran nuclear deal // CNN. 3 March 2017.

URL: <http://www.cnn.com/2017/03/03/opinions/trump-iran-deal-andelman/>.

33 Ibid.; Harb I.K. Obstacles to President Trump's options on Iran // Arab Center Washington DC. 14 March 2017. URL: <http://arabcenterdc.org/policy_analyses/obstacle-trump-iran-jcpoa/>.

${ }^{34}$ Knickmeyer E. Russian offensive hailed in Mideast // Washington Post. 30 August 2008. URL: <http://www.washingtonpost.com/wpdyn/content/article/2008/08/29/AR2008082903127.html? sid $=$ ST2008083000507>. 